\title{
Mengembangkan Keterampilan Menulis Arab Tingkat Dasar di Masjid Baital Makmur Konang Barat Galis Pamekasan
}

\author{
${ }^{1}$ Moh. Iqbal Fachrullah Abul Jihad, ${ }^{2}$ Eva Nikmatul Rabbianty \\ Institut Agama Islam Negeri Madura \\ 1iqbal.abjad@gmail.com, ${ }^{2}$ eva@iainmadura.ac.id
}

\begin{abstract}
Arabic writing skills in the millennial era is very important. However, only a few children like and can read and write Arabic well. One of the activities that can develop and strengthen children's Al-Qur'an writing abilities and skills is by implementing basic Arabic writing learning activities. This article will discuss learning basic Arabic writing with the children and the benefits of learning it. This study was obtained based on data collected during the researcher's implementation of the SCSFH (Student Community Service From Home) program. One of the activities the researchers carried out was a basic Arabic writing learning program at Baitul Makmur Mosque, Konang Village, Galis, Pamekasan. In this lesson, we used basic Arabic writing teaching, such as teaching how to write Arabic letters, connecting Arabic letters, copying Arabic letters, and writing verses of the Qur'an. The methods used also vary, such as the dictation method, lectures, the imla' method, and other cooperative learning methods such as holding various competitions to determine how far the level of student understanding of what has been conveyed by the teacher. In this activity, it was found that many students' Arabic writing skills were still below average. Although some students are considered quite good at writing Arabic, and even then because the students concerned have stepped on the secondary education level, for more satisfying results, this basic level Arabic writing training activity should be carried out continuously and preserved to maintain children's Arabic writing skills and continue developing.
\end{abstract}

Keywords: Writing Skills; Arabic Language

\begin{abstract}
Abstrak
Keterampilan menulis Arab di era milenial merupakan hal yang sangat penting. Namun, hanya sedikit anak-anak yang menyukai dan bisa baca tulis Arab. Salah satu kegiatan yang bisa mengembangkan dan memperkokoh kemampuan dan keterampilan tulis Al-Qur'an anak-anak adalah dengan mengadakan kegiatan pembelajaran menulis Arab tingkat dasar. Artikel ini akan membahas proses pembelajaran menulis Arab tingkat dasar dan juga manfaat dari pembelajaran tersebut. Penelitian ini disusun berdasarkan data yang dikumpulkan selama peneliti melaksanakan program KPM DR (Kuliah Pengabdian Masyarakat Dari Rumah), dimana salah satu kegiatan yang penulis lakukan adalah mengadakan program pembelajaran menulis Arab tingkat dasar di Masjid Baitul Makmur, Desa Konang, Galis, Pamekasan. Dalam pembelajaran ini, kita menggunakan pengajaran dasar,
\end{abstract}


seperti mengajar cara menulis huruf Arab, menyambung huruf-huruf Arab, menyalin lafaz Arab dan menulis lafaz atau ayat-ayat al-Qur'an. Metode yang digunakan juga bervariasi, seperti metode dikte, ceramah, metode imla', dan juga metode pembelajaran kooperatif lainnya seperti diadakannya berbagai lomba untuk mengetahui sejauh mana tingkat pemahaman murid terhadap apa yang sudah disampaikan oleh pengajar. Dalam kegiatan ini ditemukan bahwa keterampilan menulis Arab murid masih banyak yang dibawah rata-rata. Walaupun ada beberapa murid yang sudah dirasa cukup baik dalam menulis Arab, itupun karena murid yang bersangkutan sudah menginjak tingkat pendidikan menengah. Untuk hasil yang lebih memuaskan kegiatan pelatihan menulis Arab tingkat dasar ini harusnya dilakukan secara terus menerus dan dilestarikan agar keterampilan menulis Arab anak tetap terjaga dan terus berkembang.

Kata Kunci: Keterampilan Menulis, Bahasa Arab

\section{Article Info:}

https://doi.org/10.19105/pjce.v3i1.4712

Received 7 June 2021; Received in revised form 24 June 2021; Accepted 30 June 2021

2684-9615/ (02021 Perdikan: Journal of Community Engagement. This is an open access article under the CC BY-NC 4.0 license (https://creativecommons.org/licenses/by-nc/4.0/)

\section{Pendahuluan}

Pembinaan baca tulis al-Qur'an sangatlah penting bagi pengetahuan dasar agama anak-anak. Kemampuan baca tulis al-Qur'an bisa membantu anak untuk lebih cepat mengerti tentang hal-hal yang berhubungan dengan agama. Sebagaimana proses turunnya ayat-ayat al-Qur'an pertama kali di Gua Hira. Seperti yang kita tahu bahwa Nabi Muhammad diberi wahyu pertama kali berupa lima ayat pertama surat al-'Alaq (Departemen Agama Islam, 1994: 1079). Ayat-ayat tersebut sangatlah berhubungan langsung dengan pentingnya baca bulis al-Qur'an. Ayat tersebut berbunyi:

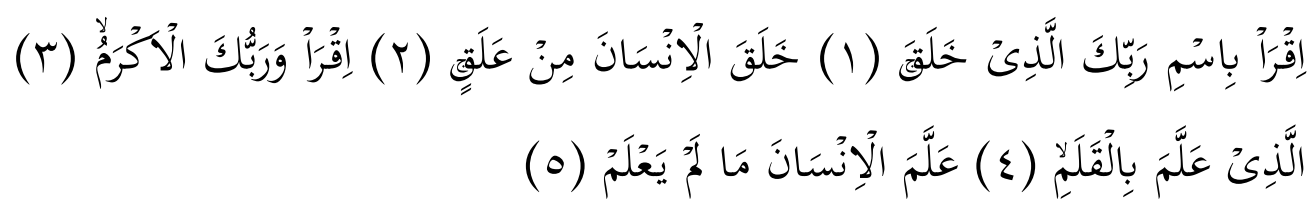

Yang artinya:

1. Bacalah dengan (menyebut) nama Tuhanmu Yang menciptakan.

2. Dia telah menciptakan manusia dari segumpal darah.

3. Bacalah, dan Tuhanmulah Yang Maha Pemurah.

4. Yang mengajar (manusia) dengan perantaran kalam.

5. Dia mengajar kepada manusia apa yang tidak diketahuinya.

Dalam firman Allah di atas tersirat bahwa membaca dan menulis alQur'an sangatlah penting apalagi dalam Pendidikan Agama Islam. al-Qur'an sebagai pedoman hidup manusia sangat berguna bagi hamba-hamba Allah 
yang berpegang teguh dan mau memahami isinya. Untuk itu, keterampilan membaca dan menulis Arab sebagai bahasa yang digunakan dalam alQur'an sangatlah diperlukan.

Di era milenial yang penuh dengan kecanggihan teknologi ini, banyak anak-anak yang terlena dan terbuai akan kenyamanan fasilitas yang serba instan. Hal itu ditunjukkan dengan adanya media internet yang sebenarnya bisa memudahkan anak-anak dalam membaca dan menulis Arab. Akan tetapi fakta di lapangan menunjukkan bahwa ternyata mereka justru menggunakan media tersebut untuk hal-hal yang membuat mereka lupa terhadap pendidikan agama ditambah dengan kurangnya pengawasan dari orang dewasa, orang tua ataupun orang terdekat mereka.

Karena seringnya mereka bermain smartphone, hal yang sangat penting seperti keterampilan membaca dan menulis al-Qur'an seakan-akan diremehkan dan dipandang sebelah mata. Mereka lebih memilih diakui pintar dan hebat dalam bermain game daripada pandai dalam membaca dan menulis al-Qur'an.

Hal tersebut tidak hanya terjadi pada anak-anak yang tinggal di perkotaan tapi juga di pedesaan. Seperti yang penulis temui di salah satu desa, tempat penulis melaksanakan kuliah pengabdian masyarakat. Di dusun Konang Barat tempat penulis tinggal sudah banyak surau, langgar, dan masjid yang menjadi wadah untuk mengajarkan pendidikan dasar agama (baca tulis al-Qur'an). Namun hal itu tidak menjamin anak-anak lebih mementingkan pendidikan agama mereka, karena kebanyakan anak-anak mengaji di langgar tidak atas kemauan sendiri tapi mengikuti temannya.

Sebenarnya hal ini tidak menjadi masalah serius karena dengan mengikuti temannya, anak akan sedikit demi sedikit terdorong untuk semangat belajar. Salah satu hal yang bisa mendorong murid semangat belajar adalah guru dan suasana pembelajaran yang menyenangkan. Sehingga memotivasi anak agar bisa menggali potensi yang ada pada dirinya.

Selama ini di Dusun Konang Barat khususnya di Masjid Baital Makmur, pembelajaran baca tulis Al-Qur'an telah diterapkan dengan metode ditetenin satu persatu dan sesekali diajarkan menulis Arab juga. Selain itu, anakanak juga diajarkan membaca kitab-kitab tentang hukum Fiqh atau yang berhubungan dengan 'ubudiyah sebagai dasar agar praktek ibadah mereka bisa sah sesuai ketentuan syara'.

Namun demikian, salah satu kemampuan yang paling rendah di kalangan murid adalah keterampilan menulis Arab yang tidak sesuai dengan kaidah penulisan Arab. Hal itu diketahui ketika anak memberi makna Arab pegon saat memaknai kitab Arab klasik, tulisan mereka kebanyakan tidak dimengerti bahkan oleh mereka sendiri. Tidak hanya itu, ketika mereka menulis ayat-ayat al-Qur'an juga masih belum tepat 
dikarenakan banyak huruf-huruf yang seharusnya ditulis di atas garis tapi malah ditulis di bawah garis. Begitupun sebaliknya.

Walaupun faktanya tulisan mereka masih kurang tepat, namun ada saja sebagian murid yang malah meremehkan keterampilan menulis Arab ini, mereka menganggap menulis Arab adalah hal sepele. Mereka menganggap sepele, karena menurut mereka menulis Arab seperti menulis huruf hijaiyah tersebut dianggap hal yang mudah dan mereka mampu menuliskannya dengan benar padahal ketika mereka menulis huruf hijaiyah saja masih kurang tepat dan tidak sesuai dengan kaidah penulisan Arab.

Melihat fakta-fakta tersebut, penulis sangat prihatin dan menjadikan alasan ini mengapa penulis mengambil tema artikel ini. Dengan adanya kegiatan KPM IAIN Madura Tahun 2020 ini, kami berniat untuk melaksanakan pembelajaran menulis Arab tingkat dasar bagi anak-anak agar keterampilan menulis Arab mereka menjadi lebih baik.

Terkait dengan pelaksanaan KPM IAIN Madura tahun 2020, sesuai dengan surat edaran Direktur Pendidikan Tinggi Keagamaan Islam (2020) yang berisi tentang kegiatan KPM (Kuliah Pengabdian Masyarakat) di perguruan tinggi Islam sehubungan dengan kondisi pandemi Covid-19, maka Rektor IAIN Madura menugaskan peserta KPM IAIN Madura tahun 2020 dilakukan secara mandiri. Atau dalam surat edaran dari menteri agama di atas disebut dengan KKN-DR (Kuliah Kerja Nyata Dari Rumah).

Ketika kegiatan KPM tetap dilaksanakan di tengah pandemi Covid-19 ini, tentunya ada berbagai batu sandungan bagi peserta KPM yang menjadi tantangan tersendiri agar kegiatan mereka bisa tetap terlaksana dengan baik. Hal yang paling penting adalah menjaga kesehatan murid jangan sampai jatuh sakit atau bahkan terjangkit wabah tersebut.

Dimasa pandemi ini juga, murid-murid, khususnya mereka yang bersekolah di sekolah formal diwajibkan untuk belajar dari rumah. Hal itu menyebabkan mereka lebih banyak waktu mereka di rumah. Dan itu juga menjadi salah satu faktor yang menyebabkan murid lebih banyak waktu untuk bermain.

Maka dari itu, rasa malas, bosan dan semacamnya bertumpuk dipikiran mereka ketika mereka diajak untuk belajar. Hal ini juga menjadi tantangan bagi peserta KPM untuk membuat suasana lebih menyenangkan agar pembelajaran yang sasarannya adalah murid-murid di tingkat dasar dapat menerima pelajaran dengan baik.

Dalam kegiatan menulis Arab ini, murid-murid diajarkan materi dasar seperti menulis huruf Hijaiyah hingga materi yang cukup sulit seperti menulis Arab dengan didikte. Hal ini dilakukan untuk melatih keterampilan menulis Arab murid agar lebih baik lagi dan juga sesuai dengan ketentuan kaidah penulisan Arab. 
Melaksanakan kegiatan KPM ditengah wabah Covid-19 tidaklah mudah. Maka dari itu untuk membantu melancarkan kegiatan menulis Arab ini, penulis menggunakan beberapa metode pengajaran, seperti menulis huruf, menyambung huruf sampai dengan didikte (Fadhilah, 2020). Cara ini dipilih agar ustaz lebih mudah menyampaikan materi dan murid lebih mudah menerima apa yang disampaikan. Karena melihat keadaan siswa yang masih perlu banyak dibina dalam hal penulisan Arab.

Sebenarnya, ketika melihat zaman yang serba canggih ini, dalam menulis Arab ada berbagai cara untuk mengajarkan murid mengetahui lebih dalam tentang penulisan Arab. Diantaranya dengan media cetak seperti buku-buku latihan menulis Arab dan sebagainya. Ada juga media menggunakan software atau aplikasi komputer yang dengannya, murid tidak usah capek-capek menulis Arab dengan tangan (Arifudin, 2020; Ni'mah, 2018).

Media-media tersebut sebenarnya bisa digunakan untuk membantu anak menggali keterampilan mereka dalam menulis Arab. Namun disini penulis sengaja mengambil metode Imla' agar murid benar-benar belajar dasardasar penulisan Arab. Ketika mereka sudah bisa dasar-dasar penulisan Arab, maka ketika diajarkan tentang hal-hal penulisan lainnya mereka akan lebih mudah menerimanya.

Untuk memotivasi semangat belajar murid, dalam kegiatan ini juga disertai dengan kegiatan lomba-lomba. Selain itu, kegiatan tersebut juga akan membantu menggali lebih dalam potensi keterampilan Arab dari murid-murid. Bukan untuk mencari pemenang ataupun siapa yang lebih baik dalam menulis Arab (Rahmawati, 2018: 296).

Dari berbagai fakta dan permasalahan diatas, penulis mengambil kesimpulan bahwa mewujudkan keterampilan menulis Arab di era milenial, dengan media yang serba instan sangatlah penting adanya. Dan juga dapat dirumuskan permasalahannya yaitu, apa keterampilan menulis Arab tingkat dasar tersebut, bagaimana mewujudkan murid yang terampil dalam penulisan Arab sehingga murid dapat mengetahui cara agar bisa memahami dan mempunyai keterampilan penulisan Arab.

Selain itu, apa saja faktor permasalahan dari murid ssehingga mereka meremehkan dan menyepelekan keterampilan menulis Arab ini. Agar mereka mengetahui bahwa keterampilan menulis Arab ini perlu untuk mereka pelajari sebagai pengetahuan dasar agama. Dan juga bagaimana beberapa pengajaran, seperti yang dijelaskan sebelumnya dapat diterapkan di era milenial ini, sehingga murid tetap semangat belajar di tengah pandemi Covid-19.

Pelaksanaan kegiatan ini dilaksanakan di tengah wabah Covid-19, hal ini menuntut agar kegiatan dilaksanakan sesuai dengan protokol kesehatan yang sudah diterapkan oleh pemerintah dan petugas kesehatan yang menangani pencegahan virus ini tidak menyebar luas. sehingga bagaimana 
peserta KPM, dalam hal ini penulis sendiri melaksanakan kegiatannya agar tetap sesuai protokol kesehatan yang ada.

\section{Kajian Teori}

\section{a. Hakikat Keterampilan Menulis Arab Tingkat Dasar}

Kegiatan KPM ini dikhususkan pada ruang lingkup penguatan kemampuan membaca dan menulis al-Qur'an (Lembaga Penelitian dan Pengabdian kepada Masyarakat, 2020). Dimana penguatan dan pelatihan membaca dan menulis al-Qur'an ini begitu penting untuk pengetahuan dasar agama anak. Bagaimana sudah dijelaskan sebelumnya bahwa alQur'an merupakan pedoman bagi kehidupan manusia, tak terkecuali anakanak di tingkat dasar.

\section{b. Pengertian Keterampilan Menulis Arab Tingkat Dasar}

Kata keterampilan berasal dari kata dasar "terampil" yang diberi imbuhan ke- dan -an. Kata terampil mempunyai arti cakap dalam menyelesaikan tugas; mampu dan cekatan. Ketika sudah diberi imbuhan ke dan an maka menjadi keterampilan yang berarti kecakapan dalam menyelesaikan tugas (KBBI Online, 2021). Para tokoh mempunyai definisi tersendiri tentang keterampilan, seperti yang dikemukakan oleh Soemarjadi, dan Zahri (1991) yang menyamakan keterampilan dengan kecakapan, artinya cekatan dalam menyelesaikan tugas dengan cara cepat dan benar. Apabila orang mengerjakan dan menyelesaikan tugas dengan cepat saja tidak dengan benar, maka menurut mereka tidak termasuk pada kategori orang yang terampil.

Menurut Robbins (2000: 494-495), keterampilan dikategorikan menjadi 4 , yakni sebagai berikut.

1) Basic Literacy Skill: merupakan keahlian dasar yang dimiliki oleh setiap orang, seperti kemampuan menulis, membaca, mendengarkan dan juga kemampuan berhitung.

2) Technical Skill: merupakan suatu keahlian yang didapat itu dengan melalui pembelajaran di dalam bidang teknik, misalnya mengoperasikan komputer, memperbaiki handphone, dan lain-lain.

3) Interpersonal Skill: merupakan suatu keahlian tiap-tiap orang dalam melakukan komunikasi antar sesame, misalnya seperti mengemukakan pendapat serta bekerja sama dalam tim.

4) Problem Solving: merupakan suatu keahlian seseorang dalam memecahkan masalah dengan menggunakan logikanya.

Dalam literasi yang lain dijelaskan bahwa keterampilan merupakan suatu daya untuk melakukan pekerjaan dengan mudah dan cermat. Ada juga yang mengartikan bahwa keterampilan adalah sebuah tingkat keberhasilan seseorang terhadap suatu hal yang telah dicapai dengan cara efisien dan efektif (Simarmata et al., 2020: 55-56). 
Dari berbagai definisi keterampilan di atas, dapat dipahami bahwa keterampilan adalah kecakapan, daya, atau kemampuan sesorang dalam mengerjakan tugasnya dengan cermat, efektif dan efisien. Misalnya keterampilan menulis Arab, ayat-ayat al-Qur'an atau tulisan-tulisan lain dengan cepat dan benar.

Kata menulis berarti membuat huruf, angka dan sebagainya menggunakan alat tulis seperti pena, pensil, bulpen dan semacamnya, ditulis dengan tangan dan melahirkan pemikiran atau perasaan dari penulis tersebut. Seperti halnya mengarang cerita, menulis kaligrafi dan lain-lain.

Menurut Marwoto dalam Darman (2015: 4) menjelaskan bahwa menulis adalah mengungkapkan ide atau gagasannya dalam bentuk karangan secara leluasa. Dalam hal ini, menulis membutuhkan skemata yang luas sehingga si penulis mampu menuangkan ide, gagasan, dan pendapatnya dengan mudah dan lancar. Skemata itu sendiri adalah pengetahuan dan pengalaman yang dimiliki. Jadi, semakin banyak skemata seseorang, semakin mudahlah ia menulis.

Dari pengertian menulis di atas dapat disimpulkan bahwa menulis merupakan penyampaian perasaan, pemikiran, ide dan sebagainya melalui huruf, angka dan sebagainya dengan menggunakan alat seperti bulpen, pensil dan semacamnya.

Dalam bahasa Arab, kata menulis dikenal dengan kata kitabah (katabayaktubu) yang artinya adalah menulis. Bagi murid-murid yang tidak terbiasa mendengar dan bersinggungan langsung dengan tulisan Arab, menulis Arab termasuk kategori pembelajaran yang sulit. Hal ini dikarenakan mereka lebih terbiasa menulis huruf abjad dari huruf "a sampai z" daripada menulis huruf "alif sampai ya' (2016: 181)."

Penulisan huruf latin berbeda dengan penulisan huruf-huruf Arab. Dalam tulisan latin, semua lambang bunyi dapat ditulis dengan huruf baku, tanpa harus diberi tanda tertentu, akan tetapi dalam kaidah penulisan Arab tidak seperti itu. Pada penulisan huruf latin juga lebih mudah, semua huruf latin bisa disambung dengan semua huruf setelahnya.

Sedangkan penulisan huruf Arab, tidak semua huruf Arab bisa disambung dengan huruf yang ada sesudahnya. Dari 28 huruf Hijaiyah, ada enam huruf yang tidak bisa disambung dengan huruf setelahnya, yaitu huruf alif, da, dza, ro', za', wau. Dan dua puluh dua huruf lainnya dapat disambung (Rosyidi \& Ni'mah, 2012: 99). Ada juga perbedaan dari posisi penulisan hurufnya, adapun penulisan huruf Arab juga harus memperhatikan atas garis dan di bawah garis.

Hal itu yang membedakan antara penulisan huruf-huruf latin dan juga huruf Hijaiyah. Sehingga penulisannya sedikit lebih sulit daripada tulisan latin yang baku. Jika anak didikte menggunakan bacaan latin itu juga terdengar akan lebih mudah kepada murid daripada didikte menggunakan 
bacaan Arab, dan salah satu faktornya adalah karena mereka lebih terbiasa menulis latin daripada menulis Arab.

Kata "tingkat dasar" tidak perlu dibahas secara mendalam karena dengan mencari artinya dalam kamus bahasa Indonesia, pasti kita sudah mengerti akan maknanya. Tingkat dasar berarti masa dimana anak-anak masih berada pada tahap awal.

Sehingga dalam kegiatan ini, keterampilan menulis yang dikembangkan adalah penulisan Arab di tingkat dasar jadi kegiatannya tahap demi tahap dari mulai menulis huruf Hijaiyah, menyambung kata dan kalimat sampai dengan menulis ayat-ayat al-Qur'an pada surat-surat pendek dengan tanpa menlihat mushaf. Jadi dari semua penjelasan di atas, dapat disimpulkan bahwa keterampilan menulis Arab tingkat dasar adalah kecakapan murid dalam menulis dan menyambung huruf-huruf Arab sesuai kaidahnya pada tahapan awal.

\section{c. Prinsip dalam Pengajaran Menulis Arab}

Dalam proses pembelajaran menulis Arab yaitu diantaranya:

1) Bagi orang Arab kegiatan menulis Arab memang dianggap sebagai kegiatan menulis biasa. Sedang bagi orang non-Arab bagaikan melukis sesuatu, artinya butuh ketelatenan. Bisa juga dikatakan bahwa menulis Arab bagi orang Arab termasuk cepat walaupun bagi anak-anak orang Arab, sedang bagi anak-anak yang non-Arab termasuk lambat dalam belajar menulis Arab.

2) Adanya pengaruh bahasa ibu. Ketika menulis Arab tulisan harus dimulai dari sisi kanan ke sisi kiri. Sedang pada bahasa ibu orang-orang selain orang Arab sudah terbiasa menulis dari kiri ke kanan.

3) Akurasi tulisan Arab banyak dipengaruhi dari latihan mendengarkan secara tepat (Munir, 2016:182).

\section{d. Pengajaran Menulis Arab}

1) Pengajaran menulis huruf

Dalam pengajaran ini murid belajar menggabungkan titik-titik hingga menjadi sebuah huruf. Setelah itu murid langsung belajar menulis secara langsung.

2) Pengajaran menyalin

Setelah belajar menulis huruf, murid belajar menulis lafaz-lafaz Arab dengan menyalin teks Arab dari buku atau mushaf al-Qur'an (Fadhilah, 2020: 37-38).

3) Pengajaran Imla' (dikte)

Secara etimologi imla' berasal dari Bahasa Arab yaitu amla a- yumliuimlaa an yang artinya dikte (Munawwir, 1973: 1458). Sedangkan menurut terminologi metode imla' yaitu metode yang dilakukan dengan jalan mendiktekan pelajaran di depan kelas untuk dicatat oleh murid persis dengan apa yang dikatakan guru. Definisi ini dikemukakan oleh Abdul 
Qadir Munsy dalam bukunya Pedoman Mengajar sebagaimana dikutip oleh Depen (2010: 9).

Pengajaran imla' atau dengan didekte ini, merupakan rangkaian terakhir dalam belajar menulis Arab di tingkat dasar. Setelah anak belajar menulis huruf Hijaiyah satu persatu, murid belajar menyalin teks Araba dari buku dan terakhir murid belajar menulis Arab dengan didikte. Dengan pengajaran imla' ini dapat diketahui sejauh mana tingkat pemahaman murid dalam menulis Arab. Karena terkadang walaupun telah melewati berbagai tahap sebelumnya, murid masih kaku ketika menulis Arab pada saat menulis Arab dengan didikte. Jadi dalam metode ini, murid harus banyak-banyak dilatih.

\section{Metode}

Kegiatan KPM DR IAIN Madura 2020 dilaksanakan di sebuah Masjid yang terletak di kawasan Langgar Tenga (Masjid Baital Makmur) di dusun Konang Barat, desa Konang, Kecamatan Galis, Kabupaten Pamekasan. Tanggal pelaksanaannya dimulai pada tanggal 2 hingga 27 Juni 2020. Kegiatan ini dilakukan dengan pembelajaran langsung (tatap muka) namun dengan tetap mengikuti protokol kesehatan yaitu jaga jarak, memakai masker dan memberi hand sanitizer sebelum kegiatan berlangsung. Waktu pelaksanannya di malam hari setelah salat maghrib sampai jam 19.15.

Pihak-pihak yang terkait didalamnya yaitu, K. Abd. Mochtar M. selaku pengasuh Pesantren Mambaul Ulum dan pengurus masjid Baital Makmur. Ny. Hasinah pendidik santri putri, Ny. Mauidatul Hasanah A.M. ustadzah yang membantu mengajar santri putri dan murid-murid putra dan putri dari tingkat MI/SD sampai MTs/SMP.

Tempat pelaksanaan di Musholla putri dengan alat dan bahan: al-Qur'an, buku iqro' berbentuk pdf jilid 2, papan biru terbuat dari kertas karton dan selotip bening, spidol, bulpen, buku tulis dan penghapus.

\section{Hasil dan Pembahasan}

Dalam kegiatan KPM-DR IAIN Madura 2020, penulis mengambil ruang lingkup tentang penguatan kemampuan baca tulis AI-Qur'an yang lebih menekankan pada peningkatan keterampilan menulis saja (Lembaga Penelitian dan Pengabdian kepada Masyarakat, 2020). Dikarenakan kemampuan penulisan Arab yang berada di dusun Konang Barat khususnya yang mengaji di kawasan langgar tenga masih terbilang minim.

Pembelajaran yang dilakukan kurang lebih selama sebulan itu, bertujuan agar murid-murid tersebut mampu menulis Arab dengan baik dan benar. Proses kegiatan berlangsung tidak full dalam satu minggu dikarenakan hari sabtu dan hari minggu penulis jadikan untuk waktu menyusun catatan pada kegiatan yang sudah berlalu dan mengedit video yang akan disetorkan pada DPL (Dosen Pembimbing Lapangan). 
Kegiatan pengabdian tersebut dijadwalkan dengan kebiasaan pengajian al-Qur'an malam di Masjid Baital Makmur yang mana terlaksana pada malam hari. Hal itu dijelaskan pada saat hari pertama kegiatan KPM dimulai yaitu mensosialisasikan proker yang telah disusun oleh penulis sebagaimana yang ada pada gambar di bawah ini.

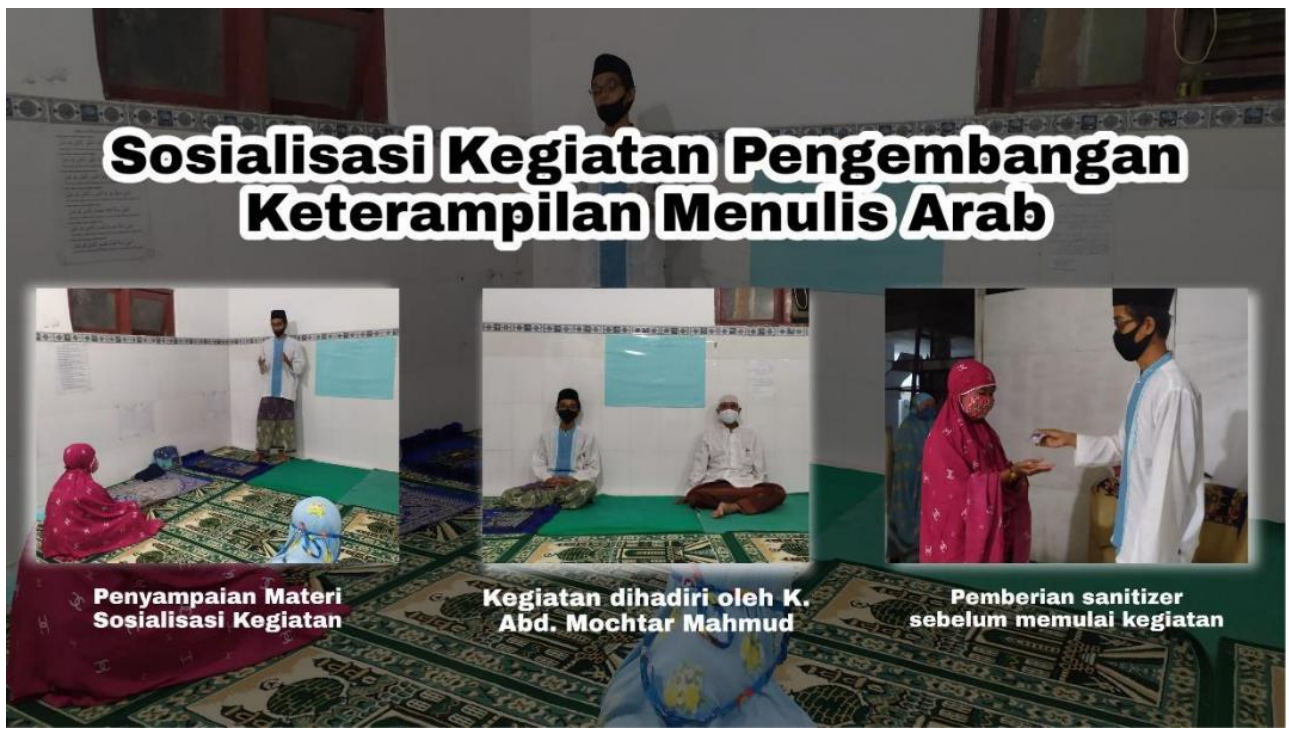

Gambar 1. Sosialisasi kegiatan pengembangan keterampilan menulis Arab

Untuk lebih rincinya kegiatan yang telah terlaksana di lapangan sama dengan yang ada dalam program kerja yang sebelumnya disetorkan pada DPL, yaitu sebagaimana termaktub dalam tabel di bawah ini.

Tabel 1. Alur kegiatan pengembangan keterampilan menulis Arab

\begin{tabular}{llll}
\hline $\begin{array}{l}\text { Nama } \\
\text { Aktivitas }\end{array}$ & Target Capaian & Target Keluaran & $\begin{array}{l}\text { Jadwal } \\
\text { Kegiatan }\end{array}$ \\
\hline Pelepasan \\
peserta KPM & $\begin{array}{l}\text { Memahami tugas } \\
\text { sebagai peserta } \\
\text { KPM DR }\end{array}$ & $\begin{array}{l}\text { Mahasiswa mampu } \\
\text { menyelesaikan KPM } \\
\text { dengan baik }\end{array}$ & $\begin{array}{l}\text { Senin, 1 } \\
\text { Juni 2020 }\end{array}$ \\
\hline Sosialisasi & Mengetahui & Mahasiswa: & Selasa, 2 \\
kegiatan & maksud & Semangat & Juni 2020 \\
Menulis Arab & diadakannya & dalam & \\
& kegiatan tersebut & mengembangkan & \\
& & keterampilan menulis & \\
& & Arab & \\
& & Murid: Mengerti & \\
& & terhadap sistem & \\
& & kegiatan tersebut & \\
& & & \\
& &
\end{tabular}




\begin{tabular}{|c|c|c|c|}
\hline $\begin{array}{l}\text { Menulis } \\
\text { huruf } \\
\text { Hijaiyah } \\
\text { dengan baik } \\
\text { dan benar }\end{array}$ & $\begin{array}{l}\text { Mampu } \\
\text { memahami } \\
\text { cara menulis } \\
\text { Hijaiyah sesuai } \\
\text { kaidah penulisan } \\
\text { Arab. }\end{array}$ & $\begin{array}{l}\text { Murid bisa menulis } \\
\text { huruf Hijaiyah } \\
\text { dengan } \\
\text { baik dan benar }\end{array}$ & $\begin{array}{l}\text { Rabu, } 3 \text { Juni } \\
2020\end{array}$ \\
\hline $\begin{array}{l}\text { Mengaji } \\
\text { Yasin } \\
\text { bersama }\end{array}$ & $\begin{array}{l}\text { Memahami bahwa } \\
\text { mengaji Yasin } \\
\text { sebagai wasilah } \\
\text { mendoakan orang- } \\
\text { orang yang sudah } \\
\text { meninggal }\end{array}$ & $\begin{array}{l}\text { Murid lancar } \\
\text { membaca } \\
\text { surat Yasin }\end{array}$ & $\begin{array}{l}\text { Kamis, } 4 \\
\text { Juni } 2020\end{array}$ \\
\hline $\begin{array}{l}\text { Pengulangan } \\
\text { menulis huruf } \\
\text { Hijaiyah }\end{array}$ & $\begin{array}{l}\text { Mengoreksi dan } \\
\text { memperbaiki cara } \\
\text { menulis anak }\end{array}$ & $\begin{array}{l}\text { Murid bisa fasih } \\
\text { dalam menuliskan } \\
\text { huruf Hijaiyah }\end{array}$ & $\begin{array}{l}\text { Jum'at, } 5 \\
\text { Juni } 2020\end{array}$ \\
\hline $\begin{array}{l}\text { Menulis cara } \\
\text { menyambung } \\
\text { dari masing- } \\
\text { masing huruf } \\
\text { Hijaiyah }\end{array}$ & $\begin{array}{l}\text { Mengetahui cara } \\
\text { sambungan dari } \\
\text { setiap huruf } \\
\text { Hijaiyah }\end{array}$ & $\begin{array}{l}\text { Murid mampu } \\
\text { menulis sambungan } \\
\text { setiap huruf Hijaiyah }\end{array}$ & $\begin{array}{l}\text { Senin, } 8 \\
\text { Juni } 2020\end{array}$ \\
\hline $\begin{array}{l}\text { Menyambung } \\
2 \text { huruf yang } \\
\text { sama dan } \\
\text { berbeda }\end{array}$ & $\begin{array}{l}\text { Memahami cara } \\
\text { menyambung } 2 \\
\text { huruf yang sama } \\
\text { dan berbeda }\end{array}$ & $\begin{array}{l}\text { Murid mampu dalam } \\
\text { menyambung } 2 \text { huruf } \\
\text { yang sama dan } \\
\text { berbeda }\end{array}$ & $\begin{array}{l}\text { Selasa, } 9 \\
\text { Juni } 2020\end{array}$ \\
\hline $\begin{array}{l}\text { Menyambung } \\
3 \text { huruf yang } \\
\text { sama dan } \\
\text { berbeda. }\end{array}$ & $\begin{array}{l}\text { Memahami cara } \\
\text { menyambung } 3 \\
\text { huruf yang sama } \\
\text { dan berbeda }\end{array}$ & $\begin{array}{l}\text { Murid mampu dalam } \\
\text { menyambung } 3 \text { huruf } \\
\text { yang sama dan } \\
\text { berbeda }\end{array}$ & $\begin{array}{l}\text { Rabu, } 10 \\
\text { Juni } 2020\end{array}$ \\
\hline $\begin{array}{l}\text { Membaca } \\
\text { selawat } \\
\text { (Mahallul } \\
\text { Qiyam) } \\
\text { bersama }\end{array}$ & $\begin{array}{l}\text { Memahami bahwa } \\
\text { selawat } \\
\text { merupakan } \\
\text { wasilah atau doa } \\
\text { kepada Nabi } \\
\text { Muhammad SAW }\end{array}$ & $\begin{array}{l}\text { Murid mampu } \\
\text { membaca selawat } \\
\text { (Mahallul Qiyam) } \\
\text { kepada Nabi }\end{array}$ & $\begin{array}{l}\text { Kamis, } 11 \\
\text { Juni } 2020\end{array}$ \\
\hline $\begin{array}{l}\text { Siapa cepat } \\
\text { dia dapat } \\
\text { (mengulangi } \\
\text { latihan } \\
\text { menulis } \\
\text { dengan } \\
\text { permainan) }\end{array}$ & $\begin{array}{l}\text { Memahami } \\
\text { dengan jelas cara } \\
\text { Menyambung } \\
\text { huruf Arab }\end{array}$ & $\begin{array}{l}\text { Murid mampu } \\
\text { menulis sambungan } \\
\text { Arab } \\
\text { dengan baik dan } \\
\text { benar }\end{array}$ & $\begin{array}{l}\text { Jum'at, } 12 \\
\text { Juni } 2020\end{array}$ \\
\hline
\end{tabular}




\begin{tabular}{|c|c|c|c|}
\hline $\begin{array}{l}\text { Menyambung } \\
\text { huruf dalam } \\
\text { satu kata } \\
\text { Arab }\end{array}$ & $\begin{array}{l}\text { Mengetahui cara } \\
\text { menyambung } \\
\text { huruf dalam satu } \\
\text { kata Arab }\end{array}$ & $\begin{array}{l}\text { Murid mampu } \\
\text { menyambung satu } \\
\text { kata Arab yang } \\
\text { dipisah }\end{array}$ & $\begin{array}{l}\text { Senin, } 15 \\
\text { Juni } 2020\end{array}$ \\
\hline $\begin{array}{l}\text { Menyambung } \\
3 \text { kata Arab }\end{array}$ & $\begin{array}{l}\text { Mengetahui cara } \\
\text { menyambung } 3 \\
\text { kata Arab }\end{array}$ & $\begin{array}{l}\text { Murid mampu } \\
\text { menuliskan } 3 \text { kata } \\
\text { Arab dengan baik } \\
\text { dan benar }\end{array}$ & $\begin{array}{l}\text { Selasa, } 16 \\
\text { Juni } 2020\end{array}$ \\
\hline $\begin{array}{l}\text { Mengulang } \\
\text { latihan } \\
\text { menyambung } \\
\text { kata Arab }\end{array}$ & $\begin{array}{l}\text { Mengetahui sejauh } \\
\text { mana murid bisa } \\
\text { menyambung kata } \\
\text { Arab. Mengoreksi } \\
\text { dan memperbaiki } \\
\text { tulisan murid }\end{array}$ & $\begin{array}{l}\text { Murid mampu } \\
\text { menuliskan kata } \\
\text { Arab dengan } \\
\text { sambungan yang } \\
\text { baik dan benar }\end{array}$ & $\begin{array}{l}\text { Rabu, } 17 \\
\text { Juni } 2020\end{array}$ \\
\hline $\begin{array}{l}\text { Membaca } \\
\text { surat Yasin } \\
\text { dan selawat } \\
\text { (Mahallul } \\
\text { Qiyam) } \\
\text { bersama }\end{array}$ & $\begin{array}{l}\text { Meningkatkan } \\
\text { tingkat kecerdasan } \\
\text { spiritual dengan } \\
\text { meyakini } \\
\text { keduanya } \\
\text { sebagai wasilah } \\
\text { agar lebih dekat } \\
\text { kepada Allah SWT }\end{array}$ & $\begin{array}{l}\text { Murid mampu } \\
\text { membaca surat } \\
\text { Yasin dan selawat } \\
\text { (Mahallul Qiyam) } \\
\text { kepada Nabi dengan } \\
\text { fasih }\end{array}$ & $\begin{array}{l}\text { Kamis, } 18 \\
\text { Juni } 2020\end{array}$ \\
\hline $\begin{array}{l}\text { Menulis ayat- } \\
\text { ayat al- } \\
\text { Qur'an } \\
\text { dengan } \\
\text { melihat } \\
\text { Mushaf }\end{array}$ & $\begin{array}{l}\text { Mengetahui cara } \\
\text { menulis ayat-ayat } \\
\text { al-Qur'an dengan } \\
\text { melihat mushaf }\end{array}$ & $\begin{array}{l}\text { Murid mampu } \\
\text { menuliskan ayat-ayat } \\
\text { al-Qur'an dengan } \\
\text { melihat mushaf }\end{array}$ & $\begin{array}{l}\text { Jum'at, } 19 \\
\text { Juni } 2020\end{array}$ \\
\hline $\begin{array}{l}\text { Menulis ayat- } \\
\text { ayat al- } \\
\text { Qur'an } \\
\text { dengan } \\
\text { tanpa melihat } \\
\text { mushaf }\end{array}$ & $\begin{array}{l}\text { Mengetahui cara } \\
\text { menulis ayat-ayat } \\
\text { al-Qur'an dengan } \\
\text { tanpa melihat } \\
\text { mushaf }\end{array}$ & $\begin{array}{l}\text { Murid mampu } \\
\text { menulis ayat-ayat al- } \\
\text { Qur'an dengan tanpa } \\
\text { melihat }\end{array}$ & $\begin{array}{l}\text { Senin, } 22 \\
\text { Juni } 2020\end{array}$ \\
\hline $\begin{array}{l}\text { Menulis teks } \\
\text { Arab dengan } \\
\text { Didikte }\end{array}$ & $\begin{array}{l}\text { Mengetahui cara } \\
\text { menulis teks Arab } \\
\text { dengan didikte }\end{array}$ & $\begin{array}{l}\text { Murid bisa menulis } \\
\text { teks Arab yang } \\
\text { didikte dengan fasih }\end{array}$ & $\begin{array}{l}\text { Selasa, } 23 \\
\text { Juni } 2020\end{array}$ \\
\hline $\begin{array}{l}\text { Questions } n \\
\text { Answers } \\
\text { seputar } \\
\text { latihan } \\
\text { menulis }\end{array}$ & $\begin{array}{l}\text { Mengetahui sejauh } \\
\text { mana tingkat } \\
\text { pemahaman murid } \\
\text { dalam menulis } \\
\text { Arab }\end{array}$ & $\begin{array}{l}\text { Murid mampu } \\
\text { menulis teks Arab } \\
\text { secara fasih }\end{array}$ & $\begin{array}{l}\text { Rabu, } 24 \\
\text { Juni } 2020\end{array}$ \\
\hline
\end{tabular}




\begin{tabular}{|c|c|c|c|}
\hline $\begin{array}{l}\text { Kompetisi } \\
\text { menebalkan } \\
\text { dan } \\
\text { mewarnai } \\
\text { teks Arab }\end{array}$ & $\begin{array}{l}\text { Mengetahui cara } \\
\text { menebalkan dan } \\
\text { mewarnai teks } \\
\text { Arab }\end{array}$ & $\begin{array}{l}\text { Murid mampu } \\
\text { menebalkan dan } \\
\text { mewarnai teks Arab }\end{array}$ & $\begin{array}{l}\text { Kamis, } 25 \\
\text { Juni } 2020\end{array}$ \\
\hline $\begin{array}{l}\text { Kompetisi } \\
\text { menulis ayat- } \\
\text { ayat al- } \\
\text { Qur'an } \\
\text { dengan } \\
\text { didikte }\end{array}$ & $\begin{array}{l}\text { Mengetahui cara } \\
\text { menulis ayat al- } \\
\text { Qur'an dengan } \\
\text { didikte }\end{array}$ & $\begin{array}{l}\text { Murid bisa menulis } \\
\text { ayat al-Qur'an yang } \\
\text { didikte oleh ustaz } \\
\text { dengan baik dan } \\
\text { benar }\end{array}$ & $\begin{array}{l}\text { Jum'at, } 26 \\
\text { Juni } 2020\end{array}$ \\
\hline Penutupan & $\begin{array}{l}\text { Menyempurnakan } \\
\text { kegiatan KPM } \\
\text { sesuai waktu yang } \\
\text { telah ditentukan }\end{array}$ & $\begin{array}{l}\text { Kegiatan ini } \\
\text { diharapkan } \\
\text { menjadi rutinitas } \\
\text { walaupun kegiatan } \\
\text { KPM berakhir }\end{array}$ & $\begin{array}{l}\text { Sabtu, } 27 \\
\text { Juni } 2020\end{array}$ \\
\hline
\end{tabular}

Dari tabel jadwal di atas, sudah sangat jelas tentang tahap demi tahap kegiatan pembelajaran menulis Arab tingkat dasar yang dipilih oleh penulis. Kegiatan-kegiatan tersebut sangat membantu dalam mengembangkan kemampuan anak dalam menulis Arab. Hal itu bisa dilihat pada saat kegiatan terakhir yaitu lomba menulis Arab. Hasil dari tulisan murid-murid yang bersangkutan sudah bisa dikatakan baik dibandingkan dengan sebelum kegiatan ini dilaksanakan.

Bahkan hasil tulisan dari pemenang pada lomba tersebut hanya ditemukan 1 kesalahan saja. Hal itu merupakan sebuah peningkatan yang membuat pengajar senang. Namun, hal itu merupakan hasil dari proses yang kurang mengenakkan sebelumnya. Pada waktu awal-awal kegiatan, keadaan murid masih dibilang memprihatinkan. Mereka menulis huruf Hijaiyah saja masih banyak yang tidak bisa (fieldnote, 3 Juni 2020).

Seperti contoh salah satu murid bernama Muhammad Fahri Rizal, ia menulis huruf Hijaiyah, semuanya di atas garis. Walaupun seharusnya huruf yang ia tulis ada di bawah garis. Kebanyakan dari murid memang seperti itu, menulis huruf shod, dlod, sin dan syin tetap di bagian atas garis.

Menulis huruf-huruf Arab memang tidak semudah menulis huruf latin (Irfan, 2019). Cara penulisan huruf Arab mempunyai kaidah tertentu yaitu: penulisan huruf Arab dimulai dari kanan ke kiri, huruf-huruf Arab ada yang dapat menyambung dan disambung. Ada juga yang hanya dapat disambung tapi tidak dapat menyambung seperti huruf alif, dal, dzal, ro', za', wawu (Hafidz, 2018: 2-5). Ada huruf yang ditulis di bawah dan ada huruf yang di atas garis. Selain itu dalam menyambung huruf, huruf Hijaiyah memiliki bentuk tersendiri ketika disambung. Baik itu di depan, tengah dan akhir kata. 
Kegiatan pembelajaran keterampilan menulis Arab ini, diselingi dengan kegiatan mengaji Yasin dan membaca selawat Mahallul Qiyam. Hal ini merupakan wasilah agar harapan mendapat ilmu yang barokah dan bermanfaat menjadi lebih mungkin didapat. Di awal-awal kegiatan KPM, murid juga mengeluh seraya meremehkan terhadap kegiatan pembelajaran menulis huruf Arab. Mereka menganggap bahwa menulis huruf Arab itu merupakan pelajaran untuk anak-anak TK. Padahal tulisan huruf-huruf Arab mereka masih belum benar.

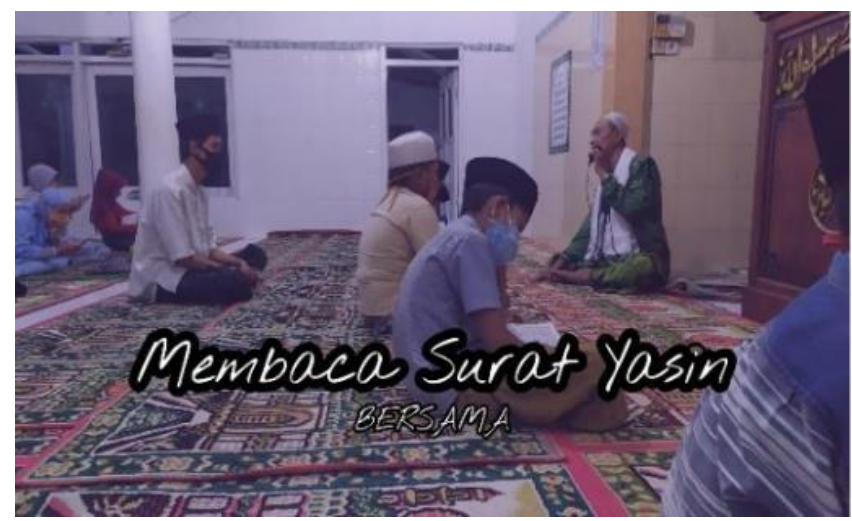

Gambar 2. Membaca surat Yasin

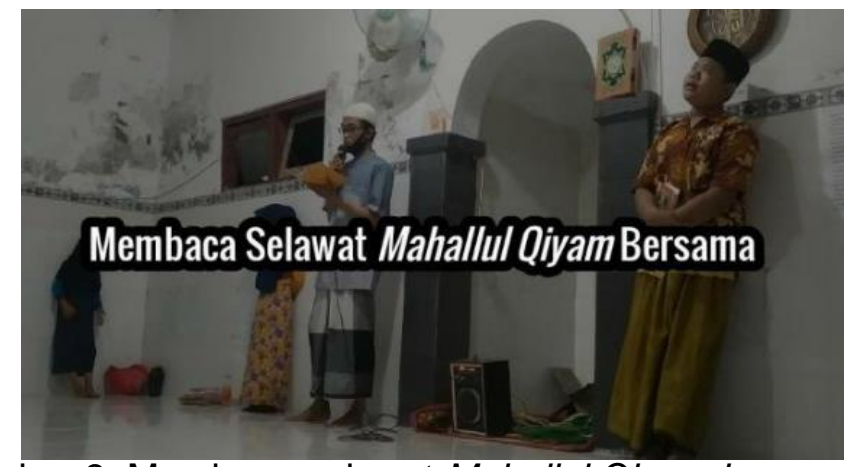

Gambar 3. Membaca selawat Mahallul Qiyam bersama

Penulis hanya tersenyum dan tetap semangat mengajari mereka, karena mereka memang masih perlu belajar lagi agar tulisan mereka benar dan baik. Pembelajaran yang dilakukan dengan metode ceramah terlebih dahulu dengan memberi murid contoh di papan dan menyuruh mereka menulisnya kembali di buku mereka masing-masing.

Melihat tabel kegiatan di atas, penulis mengira hal itu sudah cukup dalam meningkatkan keterampilan menulis Arab murid. Tapi ternyata dalam penerapannya kegiatan-kegiatan di atas hanya mampu diserap oleh muridmurid yang cepat dalam belajar. Sedangkan untuk murid yang lambat belajar, kegiatan di atas masih belum bisa diterapkan dengan maksimal. 
Mereka masih membutuhkan pengulangan kegiatan agar hasil yang mereka dapatkan lebih baik. Contohnya yang terdiri pada salah satu murid yang masih lambat belajar, ketika berlanjut pada kegiatan yang lain dia masih perlu dibimbing secara individu.

Dalam pelaksanaan kegiatan ini, metode yang digunakan juga dengan pengajaran menyambung huruf, dari dua, tiga, sampai menyambung tiga kata Arab. Selain itu juga metode yang digunakan adalah menyalin dari mushaf al-Qur'an ataupun dari teks-teks Arab yang pada saat dibacakan, teks tersebut diterjemahkan agar murid mengetahui apa maksud dari tulisan Arab yang ia tulis.

Metode lain yang penulis gunakan dalam kegiatan ini, adalah Imla' atau dikte. Hal ini dikarenakan mereka sudah pernah diajari menulis dengan metode ini. Hal ini bertujuan agar mereka lebih mudah menangkap apa yang sudah pengajar jelaskan. Namun sekali lagi, metode ini perlu diulangulang lagi untuk murid yang lambat belajar.

Tidak cukup dalam satu kali kegiatan, metode ini dipakai dan tidak dilupakan, karena pada saat penerapannya masih ada murid yang tertinggal dan bahkan tidak menulis karena mereka tidak mengetahui cara menyambung tulisan Arab di kalimat-kalimat tertentu. Sebagaimana hasil penelitian yang dilakukan oleh (Kesuma, 2016; Susanti \& Asyrofi, 2020), dimana metode Imla' terbukti efektif dalam meningkatkan kemampuan menulis Arab. Selama pelaksanaan kegiatan pembelajaran, pengajar megkolaborasikan metode dikte sambil juga memberi contoh penulisan di papan agar murid yang lambat dan cepat belajar sama-sama mengerti.

Misalnya pada kegiatan menyambung satu kata Arab, disitu murid belajar menulis dengan cara mencontoh apa yang tertulis di papan tulis.

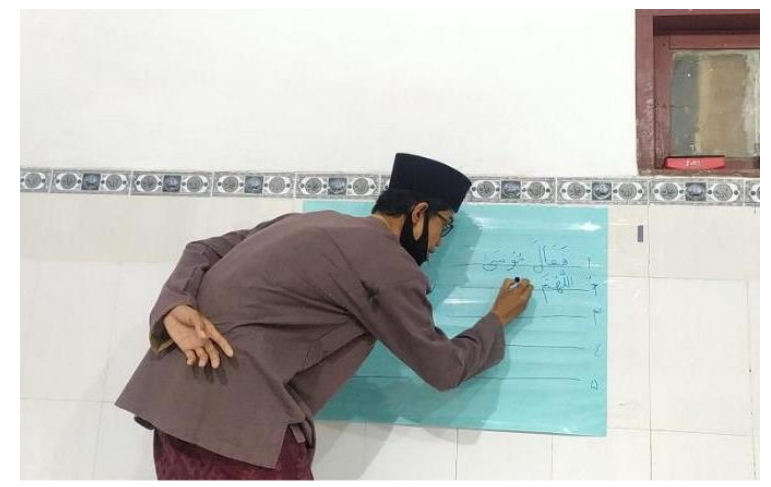

Gambar 4. Ustaz (penulis) memberi contoh penulisan Arab di papan

Pengajar menulis huruf dengan dipisah dan murid menuliskannya di buku mereka masing-masing dengan disambung. Sambil mencontohkannya di papan, pengajar juga mendikte kata Arab untuk melatih kepekaan murid dalam menulis kata Arab. Begitupun sebaliknya saat kegiatan menulis lafaz 
Arab dengan didikte, pengajar sambil sesekali menuliskan huruf-hurufnya di papan.

Contoh kalimat yang didikte adalah lafaz حسَنْ ابَبُوهُ عَاٍِِ dalam penulisan lafaz tersebut pengajar juga menuliskan huruf-hurufnya di papan secara dipisah, Karena ada beberapa murid yang lambat belajar tidak mengerti huruf apa saja yang ada pada lafaz tersebut padahal pengajar sudah mendiktenya dengan nada dan pengucapan yang jelas.

Proses pembelajaran ini juga diselingi dengan model pembelajaran kooperatif, artinya murid dibagi menjadi beberapa kelompok. Dalam satu kelompok terdiri dari 3-4 orang yang di dalamnya bercampur antara murid yang lambat belajar dan murid yang cepat belajar. Sehingga satu dengan lainnya bekerja sama agar sama-sama mengerti dalam pembelajaran yang disampaikan oleh pengajar. Hal ini dilakukan pada kegiatan menulis ayatayat al-Qur'an dengan melihat mushaf dan tanpa melihat mushaf. Seperti yang tergambar pada gambar di bawah ini.

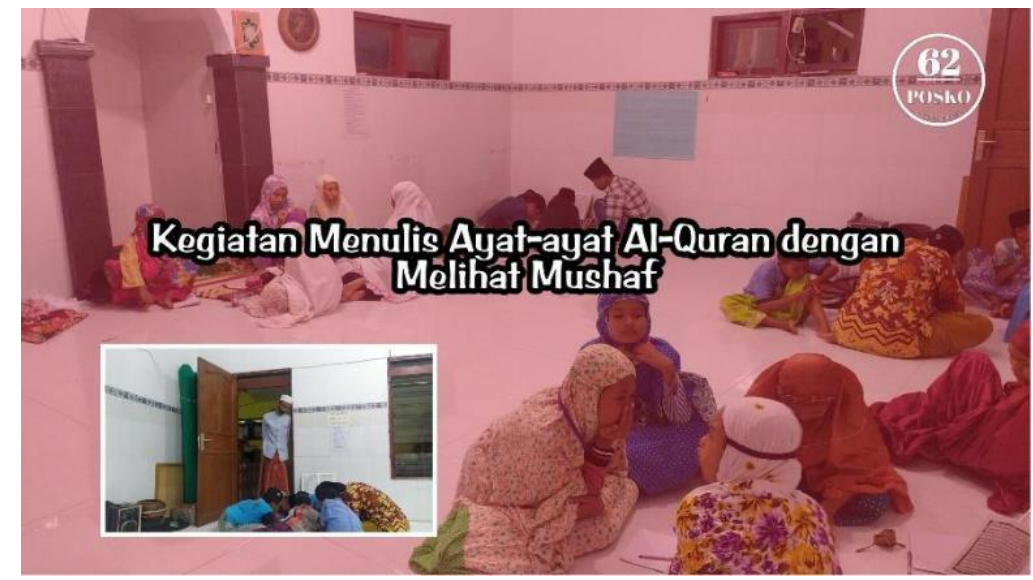

Gambar 5. Kegiatan menulis ayat-ayat al-Qur'an dengan melihat Mushaf

Hasilnya kebanyakan murid dapat bekerja sama dengan baik, tulisan mereka kebanyakan sudah tepat dan hanya membuat kesalahan penulisan pada satu atau dua huruf saja. Pada kegiatan ini, mereka disuruh menulis surat al-Ikhlas tanpa melihat mushaf, walaupun mereka sudah hafal tetap saja dalam menulis ayatnya mereka masih agak sulit, mereka masih mengingat saja seperti apa sambungan yang tepat yang sama dengan alQur'an.

Kegiatan KPM ini diakhiri dengan kegiatan lomba individu dan kelompok. Lomba kelompok berupa mewarnai dan menebalkan tulisan Arab yang disediakan oleh pengajar dan sebelum kegiatan pengajar sudah menganjurkan para murid untuk membawa pensil warna atau krayon. Lomba yang bersfat individu dilakukan dengan format Imla' atau didikte. Kegiatan tersebut sebagaimana gambar dibawah ini. 


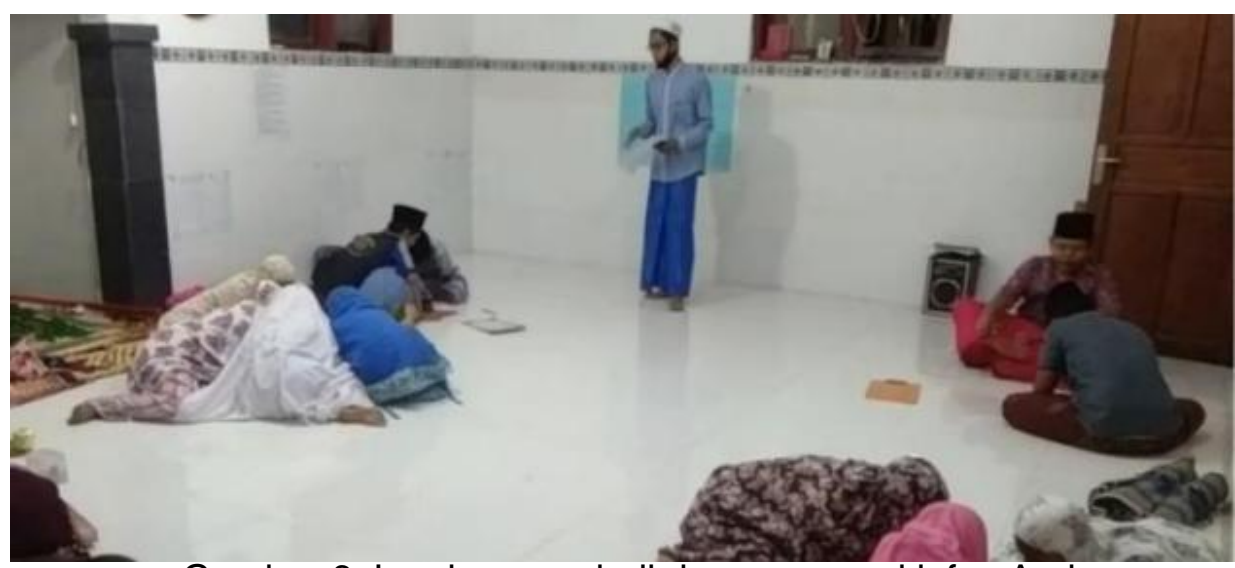

Gambar 6. Lomba menebali dan mewarnai lafaz Arab

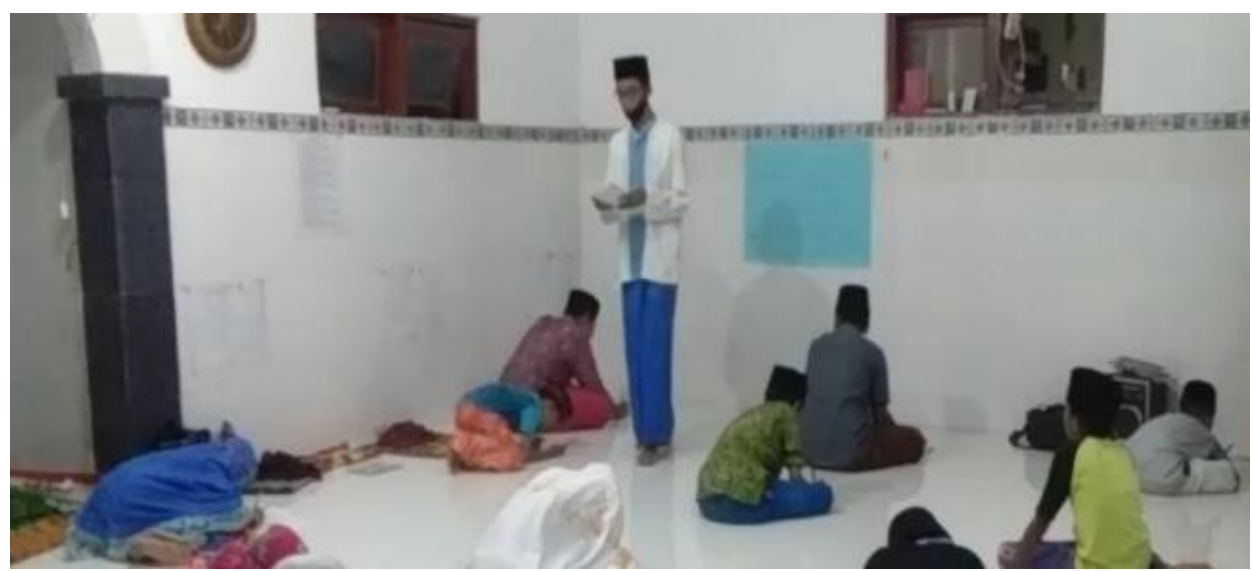

Gambar 7. Lomba menulis huruf Arab dengan didikte

Dalam setiap pelaksanaan kegiatan, pengajar tidak lupa mengingatkan mereka dan mewanti-wanti murid agar tetap menjaga kesehatan di tengah pandemi. Tidak hanya memberikan hand sanitizer saat sebelum kegiatan berlangsung, pengajar juga mengingatkan agar murid selalu mencuci tangan mereka apabila mereka baru datang bepergian dari keluar rumah.

\section{Kesimpulan}

Kegiatan KPM Dari Rumah yang dilaksanakan oleh penulis berupa ruang lingkup penguatan baca tulis al-Qur'an yang lebih menekankan pada aspek pengembangan keterampilan menulis. Pelaksanaannya dilakukan dengan cara proses pembelajaran dari mulai menulis huruf Hijaiyah sampai dengan menulis huruf dengan didikte. Tidak hanya itu pengajar juga melaksanakan lomba diakhir untuk mengetahui sejauh mana tingkat pemahaman murid terhadap apa yang sudah disampaikan oleh pengajar.

Pembelajaran di masjid Baital Makmur tersebut awalnya hanya menggunakan sistem ceramah saja. Setelah penulis melakukan 
pembaruan, penulis menerapkan sistem pembelajaran yang bervariasi agar potensi yang ada pada murid-muridnya bisa digunakan dengan baik. Seperti menggunakan metode Imla' dengan model pembelajaran berkelompok (kooperatif). Hal itu mendukung potensi anak bisa diasah dengan baik. Sehingga anak-anak yang lambat belajar bisa menyusul terhadap kemampuan anak-anak yang cepat belajar. Hasilnya, selama kegiatan KPM DR berlangsung murid-murid di masjid Baital Makmur yang terletak di desa konang tersebut sudah mampu untuk menulis Arab dengan lebih baik yang sesuai dengan kaidah penulisan arab. Murid yang awalnya tidak paham cara menyambung satu huruf dengan huruf lainnya menjadi paham dan tahu cara menyambung huruf dengan benar.

Kegiatan Pengembangan keterampilan menulis Arab yang dikemas dalam kegiatan KPM DR ini sangatlah bermanfaat bagi lembaga pendidikan Qur'an, ustaz-ustazah, serta murid-murid yang ada di masjid Baital Makmur untuk senantiasa melestarikan dan memperkuat pemahaman tentang pengetahuan baca tulis al-Qur'an. Lebih dari itu, penulis juga berharap tulisan ini dapat memberikan kontribusi pemikiran dalam mengembangkan pengetahuan dan pemahaman khususnya di bidang keterampilan baca tulis al-Qur'an.

\section{Daftar Pustaka}

Arti kata terampil-Kamus Besar Bahasa Indonesia (KBBI) Online. (2021). Retrieved 18 June 2021, from https://kbbi.web.id/terampil

Dalman. (2015). Keterampilan Menulis. Jakarta: PT. Raja Grafindo Persada. Departemen Agama Islam. (1994). Al-Qur'an dan Terjemah. Madinah alMunawwaroh: Mujamma' Malik Fahd.

Depen, A. (2010). Pelaksanaan Metode Imla' oleh Guru dalam Pembelajaran Arab Melayu di SLTPN 04 Bangkinang (Skripsi). UIN Syarif Kasim Riau, Pekanbaru.

Direktur Pendidikan Tinggi Keagamaan Islam. Surat Edaran Nomor B713/DJ.I.III/TL.00/04/2020 tentang Tidak Lanjut Edaran Direktur Jenderal Pendidikan Islam Nomor 697/03/200 di Bidang Litapdimas (Penelitian, Publikasi IImiah, dan Pengabdian kepada Masyarakat). , (2020).

Fadhilah, A. N. (2020). Penerapan Metode Imla' dalam Meningkatkan Keterampilan Menulis Bahasa Arab Siswa Kelas V MI Muhammadiyah Lumajang (Skripsi). Universitas Islam Negeri Maulana Malik Ibrahim, Malang.

Hafidz, M. (2018). Imla' Aplikatif. Jakarta: Gramedia.

Irfan, H. (2019). Analisis Faktor-Faktor Kesulitan Menulis Huruf Abjad Bahasa Arab. Lisanan Arabiya: Jurnal Pendidikan Bahasa Arab, 3(2), 129-152. doi: 10.32699/liar.v3i2.1054 
Kesuma, G. C. (2016). Penerapan Metode Imla' untuk Meningkatkan Keterampilan Menulis Bahasa Arab Peserta Didik Kelas X SMA IT Pondok Pesantren Al-Mujtama' Al-Islami Karang Anyar Lampung Selatan. Jurnal Al Bayan: Jurnal Jurusan Pendidikan Bahasa Arab, 8(2), 33-52. doi: 10.24042/albayan.v8i2.363

Lembaga Penelitian dan Pengabdian kepada Masyarakat. (2020). Petunjuk Teknis (Juknis) KPM IAIN Madura. Pamekasan: IAIN Madura.

Munawwir, A. W. (1973). Kamus Arab-Indonesia Al-Munawwir.

Munir. (2016). Perencanaan Sistem Pengajaran Bahasa Arab. Jakarta: Kencana.

Ni'mah, K. (2018). Implementasi Media Papan Mahir Bahasa Arab dalam Pembelajaran Maharoh Kitabah. DAR EL-ILMI: Jurnal Studi Keagamaan, Pendidikan dan Humaniora, 5(2), 93-114.

Rahmawati, L. (2018). Penerapan Metode Musabaqoh Bithoqoh Mukhtalithul Kalimah (MBMK) untuk Meningkatkan Hasil Belajar Maharah Al-Kitabah Siswa MAN 1 Yogyakarta. Al Mahāra: Jurnal Pendidikan Bahasa Arab, 4(2), 275-299. doi: 10.14421/almahara.2018.042-07

Robbins, S. P. (2000). Teori Organisasi (Y. Udaya, Trans.). Jakarta: Acam.

Rosyidi, Abd. W., \& Ni'mah, M. (2012). Memahami Konsep Dasar Pembelajaran Bahasa Arab. Malang: UIN Maliki Press.

Simarmata, J., Hamid, M. A., Ramadhani, R., Chamidah, D., Simanihuruk, L., Safitri, M., ... Salim, N. A. (2020). Pendidikan di Era Revolusi 4.0: Tuntutan, Kompetensi \& Tantangan. Medan: Yayasan Kita Menulis.

Soemarjadi, M. R., \& Zahri, W. (1991). Pendidikan Keterampilan. Jakarta: Depdikbud.

Susanti, S., \& Asyrofi, S. (2020). Efektivitas Metode Imlā' Manzūūr dalam Meningkatkan Keterampilan Menulis Bahasa Arab Siswa Madrasah Tsanawiyah. Aphorisme: Journal of Arabic Language, Literature, and Education, 1(2), 1-22. doi: 10.37680/aphorisme.v1i2.439 